\title{
7 TOWARDS AN INTERNATIONAL UNIVERSITY. A PROFESSORSHIP AT 1 THE FRANZ JOSEPH UNIVERSITY (CLUJ-NAPOCA) IN 1901
}

\section{Ildikó P. Varga}

Babeș-Bolyai University, Cluj-Napoca, E-mail: ildikovus@yahoo.com

\section{Acknowledgements}

This paper has been presented at the Fourth international conference on Baltic and Nordic Studies in Romania Empire-building and Region-building in the Baltic, North and Black sea areas hosted by the Romanian Association for Baltic and Nordic Studies and Ovidius University of Constanta, May 24-26, 2013. Supported by a grant from Iceland, Liechtenstein and Norway (Finantat prin fonduri donate de Islanda, Liechtenstein si Norvegia).

\begin{abstract}
The Franz Joseph University in Kolozsvár (now Cluj-Napoca, Romania) was the second modern university in the Kingdom of Hungary and it was founded in 1872. This paper presents a micro-historical investigation of a case from 1901, when the University considered inviting a Finnish linguist to the Department of Hungarian and Comparative Linguistics after the death of the Hungarian Jewish Professor Ignác Halász. The study sheds light on the arguments made to justify the need for a foreign professor and why this plan was not realized and on the role played by Emil Nestor Setälä, the professor of Finnish language and literature at the University of Helsinki, in the appointment process. The study is based on the personal correspondence of one of the candidates, Béla Vikár and the official documents of the University.

\section{Rezumat}

Universitatea Franz Joseph din Kolozsvár (acum Cluj-Napoca, România) a fost cea de a doua universitate modernă din Regatul Ungariei şi a fost fondată în 1872. Lucrarea prezintă o investigație micro-istorică a unui caz din 1901, când Universitatea a invitat un lingvist finlandez la Departamentul de Maghiară şi Lingvistică Comparată, după moartea profesorului maghiar evreu Ignác Halász. Studiul clarifică argumentele aduse pentru a justifica necesitatea unui profesor străin şi de ce acest plan nu a fost realizat, dar şi rolul jucat de Emil Nestor Setälä, profesor de limba şi literatura finlandeză de la Universitatea din Helsinki, $\hat{n}$
\end{abstract}


procesul de numire în funcție. Studiul se bazează pe corespondența personală a unuia dintre candidați, Béla Vikár şi pe documentele oficiale ale Universității.

Keywords: Franz Joseph University, Cluj, professorship, application process, 1901, Béla Vikár, E. N. Setälä, Heikki Paasonen

\section{Introduction}

The present paper is going to investigate the circumstances of the filling of the vacant professorship of Hungarian and comparative linguistics at the University of Cluj in 1901, attempting to describe the application process for the position. A special focus will be given to the factors due to which the name of a Finnish researcher arose in connection with the open position, as well as to the role played by Emil Nestor Setälä ${ }^{1}$, the professor of Finnish language and literature at the University of Helsinki, in the appointment process.

The investigation is based on the personal letters of a candidate, Béla Vikár, as well as certain official documents related to the vacant professorship figuring in the records but missing from the archives of the university.

\section{Historical antecedents: the foundation and structure of the University of Cluj}

The University of Kolozsvár (today: Cluj-Napoca, Romania) was founded by royal decree in 1872 as the second modern institution of higher education in Hungary after the University of Budapest. Following its foundation, the university was given the name Royal Hungarian Franz Joseph University. The university started functioning with four faculties: a faculty of medicine, of law, of natural sciences and of arts. The faculty of arts we are presently interested in included, besides language departments, the departments of history as well. There were a total of 11 departments, this number increasing by the turn of the century to 16 . The growing number of departments was often related to the demands of the visiting professors or those occupying the vacant professorships. In 1886, for instance, József Szinnyei, chosen to fill the professorship of Hungarian literature and

\footnotetext{
${ }^{1}$ Eemil Nestor Setälä (1864-1835), linguist, professor of Finnish language and literature at the University of Helsinki, politician. He learned Hungarian from Béla Vikár among others.

176
} 
linguistics, proved unwilling to teach literary subjects. Therefore the department split in two, a separate department of Hungarian literature was established, and Szinnyei continued to work at the university as a professor of the Department of Hungarian and Finno-Ugric Comparative Linguistics until 1893, when he occupied the vacant professorship in Budapest. This practice that the teachers of the University of Cluj continued their career in Budapest was fairly common in those times.

Ignác Halász also applied for the professorship at the Department of Hungarian Linguistics in Budapest, together with Szinnyei, and after it was occupied by Szinnyei, he was appointed to Cluj. His appointment to Cluj was probably due also to the fact that Halász was of Jewish confession. Conversion to Catholicism was a kind of implicit requirement for being recruited to the University of Budapest ${ }^{2}$, Halász worked at the University of Cluj as a professor of Hungarian and comparative linguistics until his death in 1901.

In 1901 several applicants competed for the vacant position at the increasingly prestigious university. The professorship was eventually occupied by Mór Szilasi, who was also of Jewish origin.

\section{The competition}

In April 1901, the Faculty of Arts announced a competition to fill the position of professor of Hungarian linguistics, and later, on May 17, the announcement was complemented. The notifications of the Faculty of Arts regarding this issue may be found among the files of the Cluj County Branch of the National Archives of Romania. However, the records of the proceedings related to the notifications are missing, just like the records of the nominating committees.

\footnotetext{
2 "The situation of Jews in Hungary was regulated by a quite favorable legal framework due to Joseph II's emancipatory aspirations. The De Judaeis law issued in 1790 assured undisturbed life to the Jews settled in towns, they were permitted to practice any profession, attend schools and universities, pursue scientific or artistic careers. In 1840 the Hungarian Parliament confirmed and extended these rights. This meant the beginning of the formation of a Jewish intellectual class. After the Austro-Hungarian Compromise of 1867 the Hungarian Parliament adopted the law 1867/XVII., ensuring full emancipation. The first paragraph of the law states the following: <The Israelite residents of the country are declared equal with Christian inhabitants in exercising their civil and political rights.> The application of the law encountered, of course, many obstacles and prejudices. However, it was undoubtedly put into effect at the University of Cluj." György Gaal, Egyetem a Farkas utcában (Cluj-Napoca: Magyar Múszaki Tudományos Társaság, 2001), 77.
} 
Because of the incompleteness of the documentation to be found in the archives I must rely on Béla Vikár's letters in reconstructing the course of the competition. Indirect information shows that the university was disposed to invite a visiting professor from Finland in the person of Yrjö Wichmann ${ }^{3}$ or Heikki Paasonen. ${ }^{4}$ By 1901 they were both recognized FinnoUgrists, but did not yet hold a full professorship at the University of Helsinki.

Vikár's correspondence provides us with background information about professional, ethnic, religious as well as personal motives involved in the nomination procedure and the choice, too.

Vikár himself also applied for the job. Because of his personal involvement the information to be found in the letters should be treated with reservation.

\section{Béla Vikár and his correspondence}

In order to examine the letters and the information contained in them we need to know, on the one hand, who Béla Vikár was, on the other hand, we should be able to position and contextualize the letters in his correspondence as a whole.

Vikár was born in 1859 in Hetes in Somogy county, Hungary. By profession he was a parliament stenographer, but he is known for his interest and activity in the field of ethnography and literary translation as well. He was the first ethnographer to collect and record folklore by phonograph in Hungary. As a translator he translated from several languages. His bestknown work is probably the Hungarian translation of the Finnish epic, The Kalevala. ${ }^{5}$ From Finnish he translated contemporary short stories and plays,

\footnotetext{
3 Yrjö Wichmann (1869-1932) Finno-Ugrist linguist, professor of the University of Helsinki from 1920. Besides smaller Finno-Ugric languages he studied the Csángó dialect, too. Wichmann visited Hungary several times since his wife, Hermann Julie/Zsüli was Hungarian.

${ }^{4}$ Heikki Paasonen (1865-1919) was professor of Finno-Ugric languages at the University of Helsinki from 1904 till his death. He was the successor of Arvid Genetz in this position, and he was succeeded later by Yrjö Wichmann. Paasonen's wife, Paskay Mária, was also Hungarian.

5 The full translation appeared only in 1909, but Vikár repeatedly published fragments from the translation in preparation before 1904: in the Budapest Szemle in 1890 (runes 1-8), in the memorial volume entitled Hunfalvy Pál félszázados akadémiai tagsága emlékére kiadják tisztelői in 1891 (rune 9), in the Eperjesi Lapok (rune 10), in the Budapest Szemle (runes 11-15) and in the journal Erdélyi Múzeum (runes 16-19) in 1899.
} 
too, and besides Finnish he made translations from French, German, Estonian, Italian, Dutch, Norwegian, Turkish and Georgian. Vikár deserves attention also as a literary organizer and editor, as he served in several editorial boards. As a literary organizer he worked in associations having the aim of fostering intercultural relations through literary translations and organizing literary/poetic evenings/matinees. As part of these literary and cultural organizational activities and editorial work, Vikár conducted an extensive correspondence with many significant Hungarian and foreign artists of the age in Hungarian, Finnish, German and French, up to his death in 1945.

Vikár's correspondence is still unprocessed, although attempts have been made at publishing it. ${ }^{6}$ In the case of the letters written by Vikár the problem is that the legacy of recipients lies in various manuscript collections and archives in Budapest and Helsinki, but some also happen to be in the possession of private individuals and collectors.

As regards the letters written to Vikár the greatest problem is that his apartment was bombed during World War II, thus, only a part of the correspondence has been preserved. These letters are to be found currently in the Manuscript Archive of the Hungarian Academy of Sciences in Budapest. In the course of my research I have found so far about 650 letters written by Vikár, and about 200 addressed to him. Twelve of them were written in 1901. He mentions the professorship at the University of Cluj in 6 letters. The recipients were: Bernát Munkácsi ${ }^{7}-2$, E. N. Setälä - 3 and István Apáthy $^{8}-1$. The letters written to Setälä may be found in the National Archives of Finland (Kansallisarkisto) in Helsinki, the rest of the letters in the Manuscript Archive of the Hungarian Academy of Sciences (MTAK Kt.) and in the Manuscript Archive of the National Library (OSZK Kt.) in Budapest.

On the whole, the fewest letters are addressed to Apáthy: a total of seven letters, mostly linked to Vikár's editorial work, as he asks for writings or expresses his thanks for them to Apáthy. 42 letters are addressed to Munkácsi. The large number and length of the letters, as well as the topics discussed in them suggest that the correspondents were very good friends.

\footnotetext{
6 See the references.

7 Bernát Munkácsi (1860-1937) linguist, Finno-Ugrist, specialized in Udmurt and Mansi languages. Editor of the journal Etnographia between 1894-1910.

8 István Apáthy (1863-1922) zoologist, university professor, member of the Hungarian Academy of Sciences (1898). From 1890 professor at the university of Cluj.
} 
They were engaged in a constant exchange of letters, especially in the 1880s, then, by the turn of the century, the number and length of letters became reduced. Parallelly, personal questions were being replaced by professional topics. This also indicates that the friendly relationship between the two of them deteriorated.

A total of 101 letters are addressed to Setälä. These are usually quite long, and deal both with personal and professional topics. The number and length of the letters, the personal issues mentioned - eg. plans to spend the summer vacation together, the management of each other's finances in Hungary and Finland - suggest that they were very good friends. The correspondence between the two of them ceased shortly only when Vikár's first wife died, and later, at the time when Setälä moved to Budapest in the quality of Ambassador of Finland in Hungary.

\section{Letters to Munkácsi and Setälä}

In the following, let us see the letters in a chronological order. In two letters dated 27 May 1901 - that is, ten days after the official complementation of the announcement of the competition - Vikár reports that he is in Cluj in order to take over part of Ignác Halász' legacy and take it along to Budapest.

I quote the first two lines of the two letters: "I am writing these lines to you in confidence. While being here in Kolosvár to take over from Mrs Halász part of our dear friend's legacy, I received encouragement from local linguists to apply for Halász' position if you or Szilasi were not willing to apply. As I see, Zolnai would not be accepted by the university, and they are averse to Melich, too, because he is sent by Szinnyei, and they do not accept anybody's influence in this matter." Vikár to Bernát Munkácsi, MTA Kt. Ms 10285/ö

"I came in here to Kolosvár, to take over from Ignác Halász' widow the literary legacy of my late friend, and imagine: all those teachers at the university who are most closely interested in Halász' department, encourage me to apply as Halász' successor. The reason for this encouragement is not that they would consider me the strongest available choice to replace the deceased, but because no better candidate, who would also know Finnish, has applied. Namely, the two aspirants this far are Gyula Zolnai and János Melich." Béla Vikár to E.N. Setälä, KA VAY 5466. 
Apparently the letters contain the same information: the professors of linguistics invite Vikár to apply for the position. It turns out, however, from the letter written to Munkácsi, that only if the recipient himself or Mór Szilasi does not apply. The lines written to Setälä suggest that there would be only three candidates, of whom Vikár has the best chances due to his competence in Finnish language. The question is whether Munkácsi was really being considered for the position. It seems probable that he was. This fact could by no means be omitted from the letter written to Munkácsi, because he was quite certainly aware of it. From Setälä the information was withheld because the letter would not have reached its goal otherwise. Vikár wrote to the professor of the University of Helsinki to ensure his support for himself. Among the main points of his "curriculum vitae" sent to Setälä he included the fact that he had been Budenz's student and disciple, and in 1889 he worked as Budenz's assistant, too. He also emphasized his Finnish language skills, which he had perfected during his study tour in Finland in 1889 through participating in ethnographic collecting trips and Setälä's university lectures. Besides, he attached importance to his work as a collector of Hungarian folklore, which would help him in the field of Hungarian linguistics, as part of the job offered. His Finnish language skills, on the other hand, would be of aid in the field of Finno-Ugric comparative linguistics. Vikár was, however, aware that he did not have the support of Setälä against Munkácsi. Munkácsi was better-known in Finno-Ugric scientific circles, he could boast of significant achievements, and he had applied with good chances of success for the professorship in Hungarian linguistics at Budapest in 1896. His lack of success in that case was most probably a consequence of his being of Jewish confession, too. Vikár's aim with the letter seems to have been to ask for a kind of declaration of intents from the addressee, to be sure that he is not interested in applying. In fact, through Munkácsi, he tried to obtain a similar declaration from Szilasi, too.

Unfortunately, Vikár did not name the linguists asking him to apply for the position in either of his letters. In 1901 the following appointed professors held permanent positions at the University of Cluj: Gábor Szentkatolnai Bálint as the professor of Ural-Altaic comparative linguistics; Gregoriu Szilasi, the professor of Romanian language and literature; Hugó Meltzl, of German language and literature; as well as Gyula Haraszti, of French language and literature. 
The letters also show that recruitment of teaching staff on invitation basis was being considered at the Faculty of Arts. Bernát Munkácsi's and Mór Szilasi's names figured among those to be invited. However, the documentation to be found in the Cluj archives shows that the faculty finally decided to open the position for application. This is supported by the above mentioned official documents dating from April and May 1901: the call for applications and its supplement.

\section{The listed candidates}

Among the names of eligible candidates we may find Bernát Munkácsi, Móric (or Mór) Szilasi, János Melich and Gyula Zolnai.

The most competent of them, and best known in professional circles was Bernát Munkácsi. He had published the results of his research in the field of Udmurt and Mansi languages at the end of the 19th century already. He was the author of the Votyak/ Udmurt dictionary published in 1892 in Budapest, too.

Móric Szilasi (1854-1905) studied Indo-European linguistics during his university years, committing himself then to Finno-Ugrian studies. His special field of study were the smaller Finno-Ugric languages, in 1896 he published a glossary of the Vogul language, and in 1901 a dictionary of the Mari language in Budapest.

János Melich (1872-1963) was engaged in the study of Hungarian linguistics, more exactly of onomastics. His other field of research were the Slavic languages. In 1899 he made a study trip of several months to Moscow and St. Petersburg, while he visited Helsinki as well.

Gyula Zolnai (1862-1949) was a specialist in Hungarian linguistics, his research field being language history and etymology. He had a good knowledge of Finnish, he also translated Finnish literature under the pseudonym Somkuti. (And let us note in parentheses that after Szilasi's death, in 1906 he would eventually occupy the professorship in Cluj).

One of the problems in connection with the open position was that the candidate had to be a good Hungarian linguist and specialized in FinnoUgrian studies at the same time. Among those listed above, Melich was the only one who had had no contact with Finno-Ugric languages. Gyula Zolnai was specialized in Finnish and an accomplished translator, Munkácsi and Szilasi, in turn, were engaged in the study of minor Finno-Ugric languages, they conducted field work, too, at the end of the 19th century, and published 
their results in German or in Hungarian. As regards Vikár, he could be deemed eligible as a specialist in Finnish. In terms of qualifications he, together with Munkácsi and Szilasi, had been a student of József Budenz, the (originally German) founder of the department of Ural-Altaic linguistics at the University of Budapest, and the "father of Ugric comparative linguistics."

\section{Vikár's plan in case of his election}

The common point in the above mentioned two letters is Vikár's plan proposed in the event of his appointment: the separation of the Department of Hungarian and Finno-Ugric Linguistics into a department of Hungarian and of Finno-Ugric comparative linguistics. This is the point when the Finnish names, Heikki Paasonen and Yrjö Wichmann, are first mentioned. Both were Finno-Ugrists studying smaller Finno-Ugric languages, and they spoke Hungarian well, too. Their interest in the language was, of course, strongly motivated by the fact that they both had Hungarian wives. Vikár's choice would fall to the person who would not have a position at the University of Helsinki at the time.

The plan was actually a part of his lobbying for the job, since it served as a pretext for Vikár, the writer of the letters, to inform the recipient, Setälä, on his extensive network of contacts. As a parliament stenographer he could come in contact with the leading politicians of the country. Through these personal contacts/relationships he could thus promote the separation of the department further. The invitation of a Finnish professor to the department of Finno-Ugric linguistics after the bifurcation was also part of the ambitious plan.

At a first glance, the plan appears to be feasible, but if one takes a look at the structure of the Faculty of Arts at the time it has to be realized that there was no special need for a Finno-Ugric comparative department. The reason is most simple: besides the department of Hungarian linguistics there existed a department of comparative linguistics, namely of Ural-Altaic comparative linguistics founded in 1893 and led by Gábor Szentkatolnai Bálint. Szentkatolnai, born in 1844, had studied Persian and Arabic in Vienna, and had a good knowledge of Turkish and Finno-Ugric languages. With the support of the Hungarian Academy of Sciences he had conducted research in Russia and Mongolia between 1869 and 1874, collecting linguistic 
material. ${ }^{9}$ After Ignác Halász' death and before the election of the new professor he taught Finnish language, as a substitute teacher.10 Vikár's insistence on creating a department of Finno-Ugric comparative linguistics was probably due to the fact that Szentkatolnai did not accept that the Hungarian language would be of Finno-Ugric origin, and although the UralAltaic department was set up along the lines set at the University of Budapest, Finno-Ugric contrastive linguistics was not part of the profile of the Cluj department, unlike in Budapest. Vikár, as a Finnist, wanted - and he was not alone - that Finnish would be taught by someone committed to the idea of Finno-Ugric linguistic affinity.

\section{The next letters to Munkácsi and Setälä}

During the summer vacation following the closing of the university year the issues related to the application process were also put on hold. Vikár wrote one single letter to Munkácsi, in which he touched upon the question of the Cluj professorship only briefly: "I have received a most interesting letter from Setälä. He would have stood up for me if this gesture did not appear to be against you. Thus he does not get implicated." Vikár to Bernát Munkácsi on 18.08. 1901. MTAK Kt. Ms 10285/ö

Thus Setälä, who knew Bernát Munkácsi's professional achievements well, did not write a recommendation for Vikár out of consideration for Munkácsi. He felt that through this he would take sides against Munkácsi. So the question remains whether Setälä tried to support Vikár after having learned that Munkácsi refused to accept the position in Cluj.

The issue of the open position became topical again in the new academic year. Vikár's letter written to Setälä provides us with more information on the course of events at the university: "The nomination committee chaired by prof. Meltzl, the professor of German linguistics, the rapporteur being Gábor Sz. Bálint, whom you know personally, decided to nominate only me from among the applicants, but they are going to nominate - with three votes against the chairman and the rapporteur someone who has not applied for the position, namely Mór Szilasi. As I learned later, I had as good chances as Sz[ilasi]. at the faculty, moreover, in fact it did not seem impossible that Sz[ilasi]. would drop out altogether, and

\footnotetext{
${ }^{9}$ Cf. Gaal 2001, 71.

10 Cf. Enikő M. Bodrogi and Ildikó Varga P. 'Suomen opetuksen historia Romanian Kolozsvárissa', Virittäjä 4 (2002): 586-592.

184
} 
I would be nominated alone. The explanation for this lies in the fact, that Zolnai also is supported by a considerable party - the Catholics - my antagonists thus being divided in two, inter duos litigants I could easily be the tertius, who gaudet" Vikár to Setälä on 29.10.1901. KA VAY 5466.

According to the letter thus there was a five-member committee appointed, consisting of a chairman, a rapporteur and three members. The chairman was Hugó Meltzl, the professor of German language and literature, the rapporteur Gábor Szentkatolnai Bálint. There is no information regarding the identity of the three members. The duty of the rapporteur was to present the academic career of one of the candidates. Szentkatolnai's choice fell upon Vikár, and presented him to the nomination committee. If we are to believe the writer of the letter, he earned the chairman's vote as well. However, the members nominated a candidate who had not applied for the job, namely Mór Szilasi. Vikár hoped that the voting ratio could change at the faculty meeting. In other words, besides the nominating committee, the faculty assembly also had nominating rights. Based on the information Vikár had obtained, it was Gyula Zolnai who also had the chance to get among the candidates at the faculty meeting.

About Szentkatolnai's recommendation we may also learn as much that he pointed out Vikár's translation work in his oeuvre, namely the translation of Kalevala under work: "The whole Finnish school has not done as much for the acceptance of Finnish-Hungarian affinity, as this - in his [Szentkatolnai's] opinion classic - Hungarian Kalevala." Vikár to Setälä 29.10.1901. KA VAY 5466.

As for the Finnish candidates, it was Paasonen whose name arose as a possible aspirant for the position. Vikár acted as an intermediary between the university and Paasonen, since the Associate Dean of the Faculty of Arts, János Csengeri wrote to him first in order that Vikár would ask for information from Paasonen, whether he would be interested in occupying the professorship in Cluj if it was offered to him without competition, on an invitation basis. Paasonen had sent his reply to Csengeri before Vikár's following letter to Setälä: "A few days later I sent to my friend, Csengeri (a copy of) $\mathrm{P}$ [aasonen]'s answer, which he gave to my question addressed to him under the influence of the first news about the invitation of Sz[ilas]-i (in spite of some small errors in beautiful Hungarian language and very cleverly, among other things reserving for himself the right to publish the 
results of his research work in Finland)." Vikár to Setälä on 29.10.1901.KA VAY 5466.

Vikár sent Paasonen's letter to the Ministry of Culture, too, to the minister Gyula Wlassics, who immediately informed the university on the Finnish researcher's letter. This resulted in a situation that was definitely disadvantageous for Vikár. Consequently, the letter written to Setälä was not just a report on the situation in Cluj, but also a request addressed to the professor of Finnish language and literature of the University of Helsinki, asking for support both for himself or Paasonen, and for the plan of the splitting of the department.

As it has already been mentioned earlier, their correspondence shows that Vikár and Setälä were on friendly terms with each other. However, the Finnish professor did not consider this a sufficient basis for supporting the candidacy of his friend in writing. Not even after that Munkácsi, whom he considered professionally superior to Vikár, indicated that he does not want to apply for the position in Cluj, but would continue his editorial work at the journal Etnographia at Budapest, as well as his inspectorial activities in the Jewish community. Setälä's silence could actually mean two things: on the one hand, he did not consider Vikár quite competent for the job, on the other hand, he was well aware of the fact that a letter of recommendation and support signed by him could have crucial influence on the election of the professor.

On the same day with the letter written to Setälä, Vikár also contacted István Apáthy, Professor of Zoology at the University of Cluj. A year later, in the academic year 1903-1904, Apáthy was elected rector of the university. He was certainly an influential person at the time of the writing of the letter already.

Vikár recounted in this letter, too, the nomination committee's decision. Paasonen's name arose also here as the probable successor in the professorship. Yet, this letter is more explanatory. The staff of the university had interpreted Vikár's acting as an intermediary as a gesture of withdrawal from the competition. Vikár tried to deny this in his letter, and asked for Apáthy's help, trying to convince him to support Vikár's nomination if the university would renounce the invitation of Paasonen, the Finnish professor. There is no information about any intervention on the part of Apáthy. Most probably the basically offensive tone of the letter also contributed to this, 
since Vikár lobbied for himself so, that he tried to discredit the other candidates professionally and personally as well.

\section{Personal and professional objections}

Besides the letter written to Apáthy there are also other letters revealing personal and professional controversies that were likely to affect the nomination process.

The candidates mentioned in the first round, Gyula Zolnai and János Melich, would not have been welcomed by the Cluj staff, the latter mainly because he enjoyed the support of Szinnyei - the former professor of Hungarian. From the first letter written to Setälä we may also learn that Bernát Munkácsi was not liked because he was too conflictual, and Mór Szilasi was believed to belong to Munkácsi's circle.

In the letters written to Setälä Vikár himself takes stand against the other possible candidates. Although Vikár's correspondence on the whole is not characterized by personal attacks based on religious affiliation, prejudice appears to the following extent: "It is, indeed, odd that the science of Hungarian language is transferred as a heritage from a Jew to a Jew." Vikár

\section{Béla to E.N. Setälä on 16.8.1901. KA VAY 5466.}

He considered Munkácsi and Szilasi inadequate to fill the position because they were both of Jewish faith, and the professor of Hungarian language, in his view, should not be Jewish again. As I have mentioned the previous professor, Ignác Halász was Jewish, too.

He raised professional objections mainly against Szilasi, arguing that although he specialized in minor Finno-Ugric languages and peoples, and had published dictionaries (Vogul vocabulary - in 1896, dictionary of the Mari language - in 1901), he had not conducted field research, had "never seen relative peoples, never heard relative languages spoken." Vikár to István Apáthy on 29.10.1901. OSZK Kt.

He did not, however, question Munkácsi's professional competence.

\section{The decision}

As I have already mentioned, the minutes of the election meeting may not be found among the documents preserved in the university archives, thus it is impossible to reconstruct the meeting. The index books recording the incoming and outgoing official documents of the faculty, however, include the titles of the once issued documents. One of these 
documents, a decree of the ministry issued under the number 1963/1901, bore the title: "Dr. Móric Szilasi is appointed to the Department of Hungarian and Comparative Finno-Ugric Linguistics." Another document listing the lectures to be kept by Szilasi dates from the same year, under the number 1983/1901.

Unfortunately, there is no information on the developments in connection with the nomination of the Finnish Heikki Paasonen. The letter written by vice-dean János Csengeri to Vikár has been most probably destroyed in wartimes in the bombing of Vikár's house. The Minister's letter addressed to the university, to which Paasonen's answer had been attached, came probably to the same fate as the records of the meetings and most of the documents from the years 1901-1902: during moving to Budapest and then to Szeged, as a consequence of the peace treaties ending World War I, then during the return following the Vienna Treaty of 1940 - according to which Northern Transylvania was attached to Hungary - a significant part of the documents were lost.

The internationalization of the university referred to in the title happened thus on two levels, even if it did not yet produce tangible results. On the one hand, the name of a foreign candidate, the Finnish Paasonen came up during the nomination process, on the other hand, the lobbying for the position in question spread to an international level, implying an influential Finnish professor of the University of Helsinki, E. N. Setälä, whose support was sought by candidates.

\section{References:}

\section{A. Archives:}

Arhivele Naționale ale României, Cluj-Napoca (National Archives of Romania,

Cluj county Branch, ANR) Universitatea "Ferencz József" 908.

Kansallisarkisto, Helsinki (National Archives of Finland, KA) VAY 5465-5466.

Magyar Tudományos Akadémia Kézirattára, Budapest (Manuscript Archive of the Hungarian Academy of Sciences, MTAK Kt.) Ms 10285/ö.

Országos Széchényi Könyvtár Kézirattára, Budapest (National Széchényi Library, OSZK Kt.). 


\section{B. Books and articles:}

Bakos, József. 'Adatok a Thaly-vitához (Vikár és Györffy István levelei Harsányi Istvánhoz)', Egri Pedagógiai Főiskola Évkönyve 3 (1957): 541542.

Gaal, György. Egyetem a Farkas utcában (Cluj-Napoca: Magyar Múszaki Tudományos Társaság, 2001).

Kristó, Judit. 'Vikár Béla levelei Finnországba (Bernard Fredrik Godenhjelmnek, Arvid Genetznek, Pietari Päivärintának, Julius és Kaarle Krohnnak)', Somogy 2 (1986): 49-53.

Molnár Bodrogi, Enikő and Varga P., Ildikó. 'Suomen opetuksen historia Romanian Kolozsvárissa', Virittäjä 4 (2002): 586-592.

Vikár, Béla. 'Levél Téglás Gézának', Gyorsirási Szemle 3 (1904): 55-56.

\section{Web postings}

http://www.kansallisbiografia.fi 